\title{
Mental Model Analysis of Biogas Energy Perceptions and Policy Reveals Potential Constraints in a Japanese Farm Community
}

\author{
Masayasu Asai ${ }^{1, *}$, Takashi Hayashi ${ }^{1}$ and Mitasu Yamamoto ${ }^{2}$ \\ 1 Policy Research Institute, Ministry of Agriculture, Forestry and Fisheries (PRIMAFF), 3-1-1, Kasumigaseki, \\ Chiyoda-ku, Tokyo 100-0013, Japan; th8841@affrc.go.jp \\ 2 Graduate School of Commerce, Major in Entrepreneurship, Otaru University of Commerce, Midori 3-5-21, \\ Otaru, Hokkaido 047-8501, Japan; mitasu@res.otaru-uc.ac.jp \\ * Correspondence: asaim@affrc.go.jp; Tel.: +81-3-6737-9089; Fax: +81-3-6737-9600
}

Received: 9 November 2018; Accepted: 29 December 2018; Published: 4 January 2019

\begin{abstract}
Biogas systems are complex and involve many local stakeholders who produce and utilize energy and digestate. If the systems are managed properly, they offer environmental and socioeconomic benefits to the community. However, further expansion may be challenging when differences in values and perspectives exist among stakeholders. This study analyzed perceptions among local biogas stakeholders by using a mental model approach. A local community in a northern Japanese island was chosen as a case study, and 22 stakeholders were asked to develop individual mental models of the biogas system. We found that many stakeholders shared the cognitive benefits of biogas, while there were perception differences regarding digestate use. Arable farmers mentioned technical and non-technical constraints for accepting digestate, while dairy and non-farmers were ambivalent about these demand-side constraints. This perception difference may lead to potential obstacles for future expansion of biogas systems in the region. Therefore, biogas policy should incorporate actions for better usage of digestate. These include the mandatory planning of digestate use when designing a new biogas plant, as well as actions to improve the attractiveness of digestate for arable farmers. These findings are useful for other livestock-intensive areas where the number of biogas plants is rapidly increasing but digestate management is yet organized.
\end{abstract}

Keywords: biogas; digestate; stakeholder; mental models; dairy and arable farmers; circular economy

\section{Introduction}

There has been a steady increase in the number of biogas energy plants available worldwide, especially in regions with high animal density [1,2]. If a biogas plant has been installed properly, anaerobic digestion of animal wastes and residues produces biogas and digestate. Biogas can be used to produce heat and electricity. It can also be used to fuel vehicles after upgrading the quality of natural synthesis gas or biomethane [3]. This renewable energy can replace fossil fuels and can provide a more self-sufficient energy supply. Moreover, in comparison with traditional manure storage, anaerobic digestion of animal manure avoids large greenhouse gas (GHG) emissions [4]. The digestate, which is the end-product of anaerobic digestion, can be used as an alternative to chemical fertilizers [5]. Therefore, biogas systems, which have low input costs, can lead to efficient organic waste recycling [1], giving them a high potential to fulfill multiple environmental and socioeconomic goals that contribute to a more bio-based circular economy [6,7].

A number of studies have assessed the constraints and actions for the uptake of agricultural biogas systems in different parts of the world [8-15]. For instance, Tranter et al. [10], based on a survey with 381 farmers as "possible adopters" of on-farm biogas plant in England, found that the critical barriers include 
high capital costs of installing plant and doubts about the economic returns being high enough. Similar results were reported by Brudermann et al. [12] from Switzerland with the analysis of the strengths, weakness, opportunities, and threats (SWOT analysis) of agricultural biogas production. They conclude that such plants will only succeed in contributing to sustainable energy supply goals when economic and political conditions are favorable over the long term. Beside the economic issues, Rupf et al. [13] found that limited training for biogas users and insufficient follow-up services were the key barriers in Sub-Saharan Africa; therefore, the sharing of knowledge and technical improvement to suit the needs of the intended user may promote further up-take of biogas systems. Furthermore, Qu et al. [11], based on a survey with 1227 households in China, revealed that agro-climatic conditions can be decisive factors in farmers' biogas use. Technical solutions, for instance, to tackle the low productivity of biogas digesters in cold regions, thus need to be further considered. Literature reviews show that there are wide ranges of factors impacting the widespread adoption of biogas systems. However, we found that two scopes of studies for sustainable development of biogas systems are still missing.

First, we suggest that more attention needs to be paid to how various types of local biogas stakeholders perceive and understand biogas systems. Compared to other renewable energy systems, biogas systems are more complex and involve many stakeholders with different values and priorities, including local municipalities, dairy and arable farmers, engineers, and energy companies [15]. Thus, management is deeply embedded in rural institutional structure and social practices [16], giving rise to different perceptions of what constitutes the proper use of biogas and digestate. These different values and perspectives, along with power struggles, institutional barriers, a lack of participation, and uncertainty, are major sources of conflict and failure [17,18], which may prevent the widespread use of biogas systems. These challenges can be addressed by analyzing "mental models" of biogas systems among its stakeholders.

Second, although many studies have focused on the input side of livestock sectors, concentrating their resources on biogas energy production, the digestate side of biogas production has been largely neglected. Its high potential as a fertilizer seems to be well-perceived among scientists and engineers in the biogas sector $[19,20]$, but its disadvantages for practical use are not paid much attention. Only a few authors have reported that farmers are reluctant to use digestate due to its nutrient variability and effects on soil compaction when applied with a spreader [15,21]. Despite the fact that a well-functioning biogas system depends on how to handle the large amount of digestate produced [15,21], the perception of practical digestate users, i.e., arable farmers, towards digestate values and their acceptance as a fertilizer remain largely unknown.

Through the application of mental model approaches, this study aims to analyze similarities and differences in the perception among local biogas stakeholders including arable farmers. If there were any differences in perception of biogas systems, it can be potential constraints for the further expansion of systems and thus any support for this purpose needs to be considered. We focus on a local community in Hokkaido in Japan, where on-farm biogas plants have been installed over the last decade. This Japanese case study is of general interest, because a wide expansion of biogas systems is needed to make a transition to a bio-based circular economy. This requires that local users and stakeholders accept and support these projects. Since Hokkaido is the most intensive area for dairy farming in Japan, findings from this study may be useful for other livestock-intensive areas of Japan and other countries. We first introduce our case study and methodology, and we then elicit and compare mental models regarding the motivations and constraints associated with biogas implementation and actions necessary for further expansion. Finally, we discuss the policy implications for sustainable development of the biogas system.

\section{Overview of the Biogas System in Hokkaido, Japan}

Hokkaido is the northern most island of Japan (Figure 1) and contains the most intensive dairy production [22]. Due to its high livestock density, the majority of agricultural biogas plants are concentrated in Hokkaido, followed by Honshu (the main island) and then Kyushu (the southwest 
island). The number of biogas plants has increased over the last two decades. The first construction boom was triggered by the Kyoto Protocol in 1997 when more public attention was given to biogas technology to reduce GHG emissions. Furthermore, dairy farmers became more aware of its application as an appropriate manure treatment in response to the Manure Management Act implemented in 1999 [23]. In the early 2000s, new plants were constructed under the "Biomass Nippon Strategy," which was approved by the cabinet in 2002 to promote the use of biomass for energy and material production $[24,25]$. However, implementation of biogas systems began to fade out in the mid-2000s, because biogas technology was immature, and the purchase price for the biomass-generated electricity was low. As a consequence, many biogas plants were not profitable $[23,26]$. Biogas production remained stagnant until 2011, at which point public concerns over renewable energy increased due to the disaster at the Fukushima nuclear energy plant. Furthermore, the introduction of Feed in Tariff (FIT) in 2012 provided incentives to various actors to start up new biogas projects. In 2016, a partial amendment of FIT was adopted by the National Diet that ensured a fixed purchase price for 20 years for biogas-generated electricity (39 JPY/kWh, before tax) [27]. In addition, various subsidies were available for plant construction. For instance, a subsidy from the Ministry of Agriculture, Forestry, and Fisheries (MAFF) could cover $50 \%$ of construction costs [28].

As of 2016, 69 agricultural biogas plans run in Hoikaido, with a total power capacity of $8202 \mathrm{~kW}$, which is nearly five times greater than in 2011 [26]. About $90 \%$ of these plants digest cattle manure as a main feedstock for biogas production. Although most biogas plants are on-farm plants, the number of centralized biogas plants also is increasing. Indeed, an additional 10 biogas plants are under construction in Hokkaido, and half of all biogas-based electricity currently is generated by centralized biogas plants [26].

Despite the rapid spread of biogas systems in Hokkaido, biogas production is far from reaching its full potential of producing 20 times more than the level of 2016 by utilizing all manure available [29]. The primary reason continues to be the relatively high cost for plant construction and maintenance [26], as well as required expenditures for coordinating technical and institutional settings with electricity companies [30]. Furthermore, arable farmers' perception and willingness to use digestate as a fertilizer remain unknown.

\section{Materials and Methods}

\subsection{Study Site}

We chose the biogas system in Shihoro town as a case study (Figure 1). The town is well-known for its long history of introducing on-farm biogas plants (for 15 years) and high adoption ratio: 11 dairy farmers in the town have installed on-farm biogas plants. The municipality and the Japan Agricultural Cooperatives in the town (JA Shihoro) still continue their action plan for a wide expansion of biogas systems to make a transition to a bio-based circular economy.

Located on the northern edge of the Tokachi plain $\left(43^{\circ} \mathrm{N}, 143^{\circ}\right.$ E) in Hokkaido, Shihoro covers an area of $259.1 \mathrm{~km}^{2}$ and has a population of 6200 [31]. The area has a humid continental climate, having an average temperature of $6.5^{\circ} \mathrm{C}$, with the highest temperatures in August $\left(24^{\circ} \mathrm{C}\right)$ and the lowest in February $\left(-14^{\circ} \mathrm{C}\right)$ [31]. The annual precipitation in Shihoro is $900 \mathrm{~mm}$.

Because of its flat and fertile soil conditions, about $60 \%$ of total land area of Shihoro is used for farming, with 335 arable farms that grow four major crops in rotation: winter wheat (Triticum aestivum L.), beans (adzuki bean, Vigna angularis; kidney bean, Phaseolus vulgaris L.; soybean, Glycine max Merr.), sugar beet (Beta vulgaris L.), and potato (Solanum tuberosum L.) [32]. Compared to other regions in Japan, crop production in Shihoro occurs on a much larger scale, with an average farmland size of 35 ha per farm [33].

In addition to arable farming, 67 dairy farms contain about 14,500 dairy cattle, with an average of 216 cows per farm, which is two times larger than the average number in all of Hokkaido. Moreover, the number of cows per farm has increased rapidly over the last decade [22]. 
High livestock density is accompanied by the production of a surplus of animal manure, representing a considerable pollution threat for the environment in these areas. As a response to the Manure Management Act of 1999, on-farm composting has been the most common treatment of animal waste in Shihoro, and the composted manure is used by local arable famers [33]. However, manure treatment practices are changing because of the modernization and enlargement of farm management. Currently, more than half of the dairy farmers in the town use free stall barn systems, but slurry manure produced under these systems is not suitable for composting because it contains too much moisture to facilitate the decomposition process. Therefore, treatment of slurry manure through anaerobic digestion has attracted the attention of dairy farmers.

Since 2003, the municipality and the JA Shihoro have led a push to increase biogas plant installation, which has included generating construction plans, identifying suitable farmers to operate biogas plants, and applying for subsidies. There are currently 11 on-farm biogas plants in Shihoro, ranging in plant size from 64 to $300 \mathrm{~kW}$, which requires 15-68 tons of manure and residues daily [33]. After the introduction of FIT, most plant operators choose to sell all electricity produced. The co-generated heat is used for internal purposes, such as the heat required for processing milk. The digestate is used as a fertilizer: plant operators spray it on their own grassland and fields to feed crops, and the rest is distributed to the fields of neighboring farmers. The plant operators tend to provide digestate for free, or they sell it for less than composted manure. Otherwise, they exchange digestate for animal feeds.

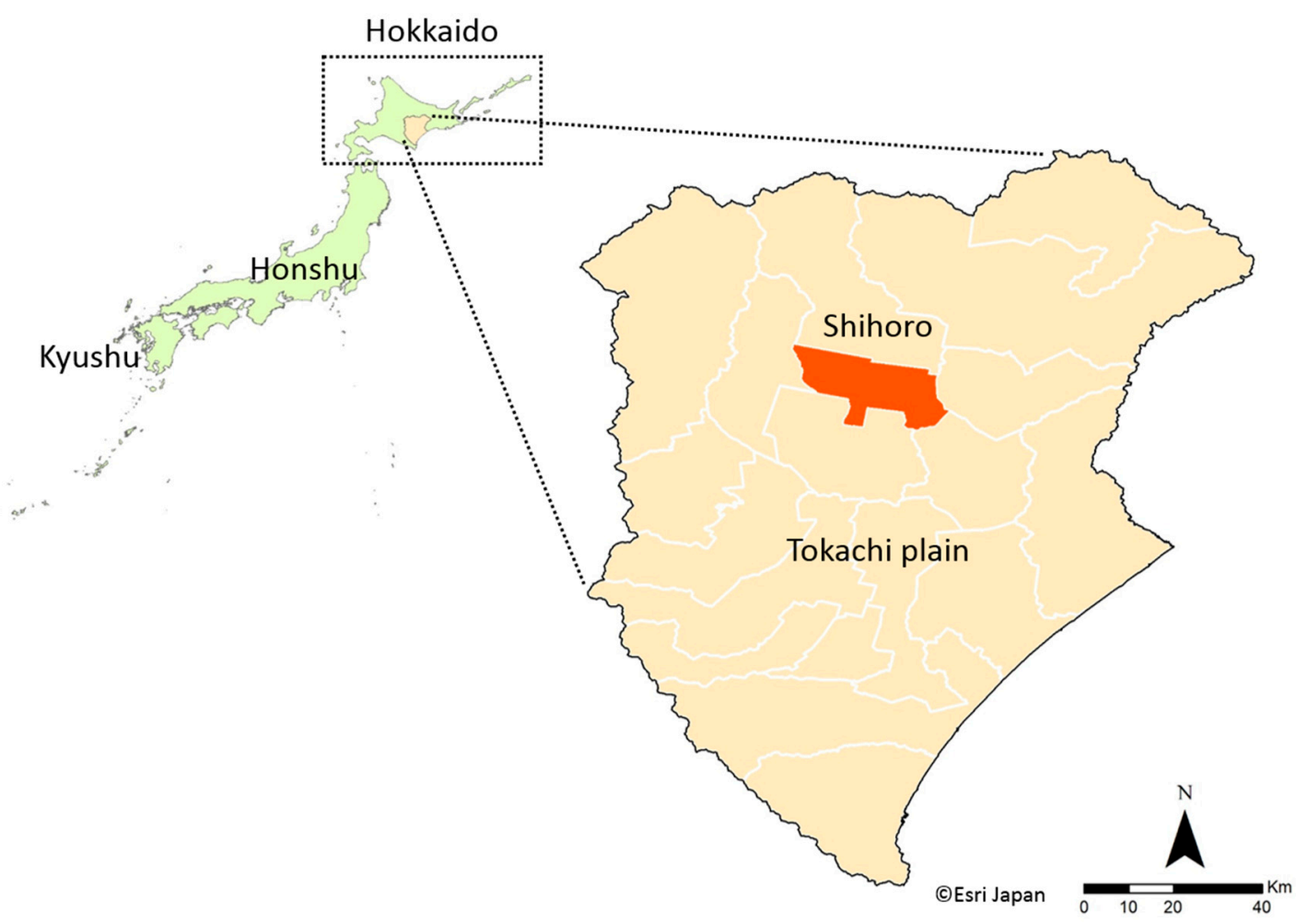

Figure 1. The location of Shihoro in Hokkaido, Japan.

\subsection{Mental Models: The Theory and the Application}

Mental models are simplified cognitive representations of an individual's or a group's internally held understanding of their external world $[34,35]$. The concept of mental models originated in psychology [36], and associated techniques have been highlighted recently as a useful approach to study stakeholders' representations of complex systems [37-39].

This approach seeks to elicit and analyze individual and group cognitive structures as a diagram by using variables and relationships among variables that underpin how people understand, 
filter, and process information about their realities $[17,35,38]$. The construction of these graphic representations is influenced by an individual's personal history (perception, experience, attitudes, and knowledge) and their interactions with their social and biophysical environment. One of the strengths of mental model is that it allows for a comparison of views of different stakeholders [39]. These graphic representations can serve as evidence to identify consistencies and conflicts between perceptions and beliefs of various stakeholders [37]. However, the weaknesses of the method are as follows: (1) the interviewees' knowledge, ignorance, misconception, and biases are all encoded in the models [40], and (2) it depends on the ability of the researcher to discern details that may or may not be applicable to a particular mapping outcome [41]. They can be partially overcome by combining the mental models of many experts or informed local people so that the accuracy of the model can be improved [40].

Mental models have been used to identify the similarities and differences in the perception of various stakeholders, engaged in various challenges of renewable energy development, such as the solar energy [42], the wind energy [43], the bioethanol [44], and the future of hydrogen-based transport [45]. For instance, Konti \& Damigos [44] recruited nine experts on the bioethanol for the construction of their cognitive maps. From the nine maps, they identified 65 variables including barriers (such as "economic crisis (increased cost)") and drivers (such as "incentives for the private sector (e.g., tax reduction)") for the production and use of bioethanol from biowaste in Greece. They also highlighted that some issues are dominant for most of the experts but some others depend on the area of interest/expertise of each expert [44]. For example, experts from the local government sector consider as crucial the factors influencing the waste management system (legislation, organization, control), omitting or neglecting the technical aspects of the bioethanol production process. On the other hand, experts from fuel companies give more weight to the potential actions when using bioethanol as fuel. Kermagoret et al. [43] used a similar approach to explore the stakeholder attitudes toward offshore wind energy in France, and found that some negative convictions were related to local issues such as project governance, natural resources, landscape, and recreational uses. These examples prove that the mental model approaches can highlight both consensus and lack thereof, among stakeholders, which can be useful in improving coordination and social learning in renewable energy management. To our knowledge, this is the first study to apply the mental model approaches to the biogas projects.

\subsection{Eliciting Stakeholder Views}

Several authors $[37,46,47]$ have reviewed the advantages and drawbacks of mental model elicitation methods. Building on their work, we followed the fuzzy cognitive mapping methodology suggested by Özesmi and Özesmi [40].

A total of 22 local stakeholders were recruited to develop individual mental models of the biogas system in Shihoro (Table 1). For the purposes of this research, "local biogas stakeholders" were defined as those with responsibility for, or long-lasting expertise and local influence in, renewable energy planning and development, livestock and arable farming, agricultural waste management, and biogas engineering and consultation. As a result, the stakeholders interviewed are of different origins: these included seven dairy farmers, seven arable farmers, two JA Shihoro officers, two biogas engineers, two municipal officers, and two researchers/consultants. They were all male between the ages of 30 and 60 . Among the seven dairy farmers, three were biogas plant operators, and four had no access to biogas plants. Three arable farmers, who used digestate on their crops, were selected, while the others were not digestate users. Unlike the large-scale centralized biogas plants, it was very unlikely that the general public is largely affected by the adoption of on-farm biogas plants, so we excluded them from the list of interviews. Due to the exploratory nature of this exercise, the limited number of interviews conducted was considered sufficient for representing various local perspectives. Previous studies with the similar methodological approach (i.e., fuzzy cognitive mapping) recruited an even smaller number of interviewees than this study. For instance, Christensen et al. [48] recruited 17 stakeholders (eight farmers and nine non-farmers) to explore their views of agri-environmental 
regulation in Scotland, while Olazabal \& Pascual [49] asked 14 stakeholders to develop the cognitive maps regarding the use of energy in the city of Bilbao, Spain.

The 22 stakeholders were asked to create mental models individually and directly. Individual elicitation minimizes the effects of power relationships and local social dynamics associated with collective elicitation, while direct elicitation helps respondents explore their cognition through the process of mapping [50]. The interviews with the stakeholders took place in Shihoro during December 2016 and January 2017. Each in-depth interview began with an overview of the project, a promise of anonymity, and an example of a simple mental model unrelated to the topic of the interview. The interviewees then were asked to create a mental model around two key questions: (1) What do you expect from biogas systems? and (2) What are the barriers to and drivers for an expansion of the biogas system in Shihoro?

First, respondents listed the variables that they thought played important roles for the key questions posed. They then placed the variable they thought was most important in the middle of a blank sheet of paper. They were informed that they could expand the number of variables as much as they deemed necessary to complete their mental model. They then placed the remaining variables around the first one, making the appropriate connections with directional arrows and indicating whether the relationship was positive or negative. The discussion continued until the interviewee was satisfied that the mental model accurately depicted his or her understanding of the system (Figure 2). All information that the interviewees provided during the development of the individual mental models also was recorded. The variables were classified as described below and used in a qualitative analysis to supplement the discussion.

\subsection{Data Analysis}

The 22 individual mental models were analyzed qualitatively and quantitatively. For better classification and understanding of causal relationships among variables, we followed the Actors, Resources, Dynamics, Interactions (ARDI) approach [51]. Based on the approach, the mental models of biogas systems were treated as social-ecological systems that were composed of the actors, the resources they use, the dynamics (processes) of these resources, and the interactions among all of these elements [51]. The biogas stakeholders (dairy and farmers, municipality, and JA Shihoro) were treated as the actors, while input, like manure, and output, like biogas and digestate, of the biogas systems were defined as the resources. Other variables related to the dynamics and interactions among actors and resources were categorized schematically into one of three variable types: motivation, constraint, and action (Figure 2). This categorization was done based on the two key questions. The answers to the question (1) about biogas expectation were classified into the "motivation" variables, which normally led to benefits for interviewees and thus motivation. Other answers to the question (2) about the barriers and drivers for an expansion of the biogas system were mainly categorized as either "constraint" or "action" variables. Constraint variables, having significant negative influence over system operation, include such as biogas plant investment and running costs, and action variables, having positive influences, include such as the continuation of the current FIT.

There are 48 motivation variables, 66 constraint variables, and 48 action variables in the 22 individual mental models. To make the mental maps directly comparable and the inter-map analysis possible, it was necessary to group all related terms having the same meaning under a common name. According to Özesmi and Özesmi [40], this process is known as qualitative aggregation. For example, "selling electricity," "FIT," "additional income," and "turning manure into energy" were combined into a variable called "additional source of income." As suggested by Gray et al. [52], to validate aggregation, subsuming variables were validated by two experts in biogas production. At the end, the variables of these three types were integrated and reduced to 20, 20, and 16 variables, respectively (Tables 2-4). 
Table 1. Profile of the 22 interviewees.

\begin{tabular}{|c|c|c|c|}
\hline Interview No. & Occupation & Age & Experiences with Biogas \\
\hline 1 & Dairy farmer & $50 \mathrm{~s}$ & Running biogas plant within a farm for 15 years. Providing digestate 12 neighbor arable farms. \\
\hline 2 & Dairy farmer & $40 \mathrm{~s}$ & Running biogas plant within a farm for five years. \\
\hline 3 & Dairy farmer & $30 \mathrm{~s}$ & Started running a biogas plant within a farm since 2016. \\
\hline 4 & Dairy farmer & $40 \mathrm{~s}$ & No access to biogas plant. \\
\hline 5 & Dairy farmer & $40 \mathrm{~s}$ & No access to biogas plant. \\
\hline 6 & Dairy farmer & $40 \mathrm{~s}$ & No access to biogas plant. \\
\hline 7 & Dairy farmer & $30 \mathrm{~s}$ & No access to biogas plant. \\
\hline 8 & Arable farmer & $50 \mathrm{~s}$ & Receiving digestate since 2016. \\
\hline 9 & Arable farmer & $50 \mathrm{~s}$ & Receiving digitate for 10 years from the neighbor biogas owner. \\
\hline 10 & Arable farmer & $40 \mathrm{~s}$ & Receiving digestate for 15 years. \\
\hline 12 & Arable farmer & $40 \mathrm{~s}$ & Receiving digestate on remote field but not on the main fields. \\
\hline 14 & Arable farmer & $40 \mathrm{~s}$ & Received digestate until five or six years ago, but not at this moment. \\
\hline 11 & Arable farmer & $30 \mathrm{~s}$ & Never received digestate. \\
\hline 13 & Arable farmer & $30 \mathrm{~s}$ & Never received digestate. \\
\hline 15 & JA Shihoro officer & $50 \mathrm{~s}$ & Coordinating biogas plant projects in the cooperative for nearly 10 years. \\
\hline 16 & JA Shihoro officer & $30 \mathrm{~s}$ & Working in the renewable energy division within the cooperative since 2015. \\
\hline 17 & Engineer & $50 \mathrm{~s}$ & Over 15 years of working experience in biogas engineering. \\
\hline 18 & Engineer & $40 \mathrm{~s}$ & Thirteen years of working experience in biogas engineering. \\
\hline 19 & Municipal officer & $50 \mathrm{~s}$ & Working on biogas development projects for six years. \\
\hline 20 & Municipal officer & $50 \mathrm{~s}$ & Over 15 years of experience in financial support for biogas development projects. \\
\hline 21 & Researcher & $50 \mathrm{~s}$ & Over 30 years of research experience in anaerobic digestion and biogas engineering. \\
\hline 22 & Researcher/consultant & $40 \mathrm{~s}$ & Doing a PhD study on biogas. Over 20 years of experience in consultation for the biogas sector. \\
\hline
\end{tabular}




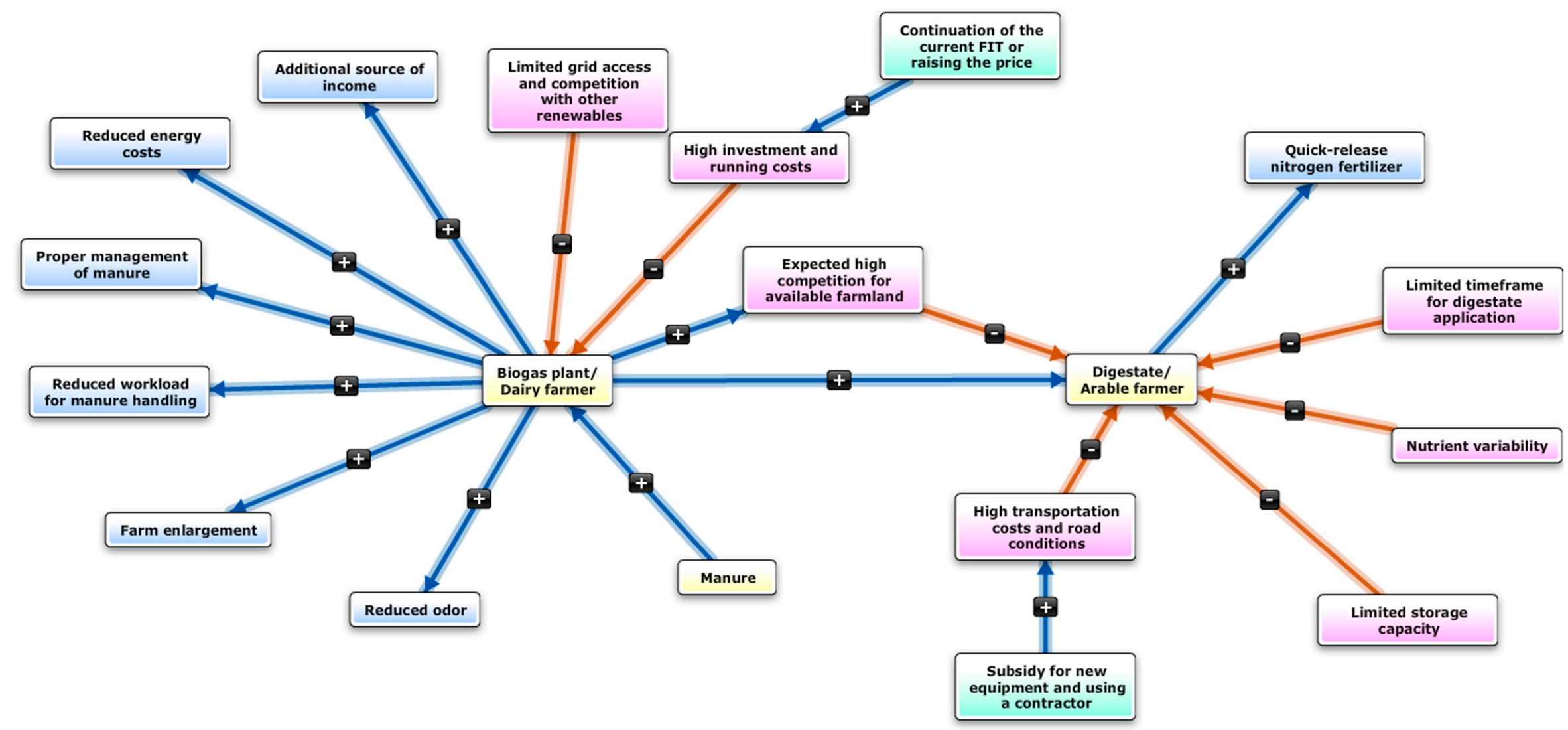

Figure 2. An example of a mental model for a dairy farmer with a biogas plant using the Actors, Resources, Dynamics, Interactions (ARDI) approach. Blue lines indicate positive relationships, and red lines represent negative relationships between variables. The yellow rectangle indicates the actor and/or the resource. Light blue $=$ motivations; pink $=$ constraints; light green $=$ actions . 
Table 2. Motivation variables identified in mental models and their citation frequency.

\begin{tabular}{|c|c|c|c|c|c|c|}
\hline Category & Variables & $\begin{array}{l}\text { Citation } \\
\text { Frequency }\end{array}$ & $\begin{array}{c}\text { Dairy Farmers } \\
\text { No. }\left(\%^{1}\right)\end{array}$ & $\begin{array}{c}\text { Arable Farmers } \\
\text { No. }\left(\%^{1}\right)\end{array}$ & $\begin{array}{c}\text { Non-Farmers } \\
\text { No. }\left(\%^{1}\right)\end{array}$ & $p^{2}$ \\
\hline \multirow{7}{*}{ Biogas plant } & Additional source of income & 12 & $5(71)$ & $3(43)$ & $4(50)$ & NS \\
\hline & Reduced energy costs through self-provision (e.g., hot water) & 10 & $3(43)$ & $3(43)$ & $4(50)$ & NS \\
\hline & Utilization of available resources & 8 & $2(29)$ & $3(43)$ & $3(36)$ & NS \\
\hline & Reduced workload for manure handling & 7 & $2(29)$ & $1(14)$ & $4(50)$ & NS \\
\hline & Farm enlargement as biogas plants can handle additional amount of manure produced & 7 & $4(57)$ & $1(14)$ & $2(25)$ & NS \\
\hline & Proper management of manure (reduced pollution/contamination risk) & 5 & $4(57)$ & $1(14)$ & $2(25)$ & NS \\
\hline & Less collective manure management by using "on-farm" biogas plant & 3 & $2(29)$ & 0 & $1(13)$ & NS \\
\hline \multirow{7}{*}{ Digestate } & Reduced odor from spreading digestate compared with compost & 14 & $4(57)$ & $4(57)$ & $6(75)$ & NS \\
\hline & Reduced fertilizer costs through digestate substitution & 11 & $3(43)$ & $3(43)$ & $5(63)$ & NS \\
\hline & Recovery of fermentation residuals in agriculture & 6 & $1(14)$ & $1(14)$ & $4(50)$ & NS \\
\hline & Quick-release nitrogen fertilizer & 6 & $1(14)$ & $2(29)$ & $3(38)$ & NS \\
\hline & High fertilizer value for grassland & 5 & $1(14)$ & $2(29)$ & $2(25)$ & NS \\
\hline & Reduction of weed seeds & 4 & $2(29)$ & $1(14)$ & $1(13)$ & NS \\
\hline & Easy and quick to spread & 2 & 0 & $1(14)$ & $1(13)$ & NS \\
\hline \multirow{6}{*}{$\begin{array}{l}\text { Local } \\
\text { community }\end{array}$} & Environmental benefits & 13 & $5(71)$ & $4(57)$ & $4(50)$ & NS \\
\hline & Improved energy security & 9 & $2(29)$ & $3(43)$ & $4(50)$ & NS \\
\hline & Improved understanding of residents toward dairy farming & 6 & $3(43)$ & 0 & $3(38)$ & NS \\
\hline & Being well-known as an "ecological town" & 4 & 0 & $1(14)$ & $3(38)$ & NS \\
\hline & Creation of new jobs & 4 & 0 & 0 & $4(50)$ & 0.019 \\
\hline & Contribution to agricultural development & 3 & $1(14)$ & 0 & $2(25)$ & NS \\
\hline
\end{tabular}

${ }^{1}$ Dark gray indicates the percentage of respondents is higher than $50 \%$, while light gray indicates response rates betw
statistically significant association $(p>0.1)$. Statistically significant associations $(p<0.05)$ are emphasized in boldface. 
Table 3. Constraint variables identified in mental models and their citation frequency.

\begin{tabular}{|c|c|c|c|c|c|c|}
\hline Category & Variables & $\begin{array}{l}\text { Citation } \\
\text { Frequency }\end{array}$ & $\begin{array}{l}\text { Dairy Farmers } \\
\text { No. }\left(\%{ }^{1}\right)\end{array}$ & $\begin{array}{l}\text { Arable Farmers } \\
\text { No. }\left(\%^{1}\right)\end{array}$ & $\begin{array}{l}\text { Non-Farmers } \\
\text { No. }\left(\%{ }^{1}\right)\end{array}$ & $p^{2}$ \\
\hline \multirow{7}{*}{ Biogas plant } & High investment and running (e.g., repair) costs & 15 & $7(100)$ & $3(43)$ & $5(63)$ & 0.081 \\
\hline & Limited grid access and competition with other renewables (solar PV) & 9 & $2(29)$ & $1(14)$ & $6(75)$ & 0.052 \\
\hline & Dependence of feed-in tariff on political circumstances/Lack of long-term perspective & 6 & $3(43)$ & 0 & $3(38)$ & NS \\
\hline & Insufficient government support, late payment, and high competition to be supported & 5 & $1(14)$ & $1(14)$ & $3(38)$ & NS \\
\hline & High manure composition variability and its treatment & 4 & $3(43)$ & 0 & $1(13)$ & NS \\
\hline & Unsure economic benefits & 3 & $2(29)$ & 0 & $1(13)$ & NS \\
\hline & Lack of use for heat generated in particular night and summer time & 2 & 0 & 0 & $2(25)$ & NS \\
\hline \multirow{11}{*}{ Digestate } & Expected high competition for available farmland to spread digestate & 10 & $5(71)$ & $3(43)$ & $2(25)$ & NS \\
\hline & High transportation costs and road conditions & 9 & $2(29)$ & $6(86)$ & $1(13)$ & 0.016 \\
\hline & $\begin{array}{l}\text { Limited timeframe for digestate application (e.g., depending on weather and seasonal } \\
\text { conditions) }\end{array}$ & 8 & $1(14)$ & $6(86)$ & $1(13)$ & 0.005 \\
\hline & Unclear impacts on yield/limited knowledge and practices & 6 & $1(14)$ & $5(71)$ & 0 & 0.005 \\
\hline & Requirement of spreading equipment and its cause of soil compaction & 6 & 0 & $5(71)$ & $1(13)$ & 0.002 \\
\hline & Preference of composted manure over liquid digestate & 6 & $2(29)$ & $4(57)$ & 0 & 0.039 \\
\hline & $\begin{array}{l}\text { Nutrient variability due to, for example, uncovered slurry tank and differences in } \\
\text { feedstock }\end{array}$ & 4 & $2(29)$ & $2(29)$ & 0 & NS \\
\hline & Low acceptance rate among neighbors/poor linkages and communication with suppliers & 4 & 0 & $3(43)$ & $1(13)$ & NS \\
\hline & $\begin{array}{l}\text { Suppliers careless about demand-side wish (e.g., spreading digestate with proper timing } \\
\text { and amount) }\end{array}$ & 3 & 0 & $3(43)$ & 0 & 0.024 \\
\hline & Limited storage capacity & 3 & $3(43)$ & 0 & 0 & 0.045 \\
\hline & Odor from spreading digestate & 2 & 0 & $2(29)$ & 0 & NS \\
\hline \multirow{2}{*}{$\begin{array}{l}\text { Local } \\
\text { community }\end{array}$} & Dissemination of information about biogas system & 2 & 0 & $1(14)$ & $1(13)$ & NS \\
\hline & Low returns to local community & 1 & 0 & 1 (14) & 0 & NS \\
\hline
\end{tabular}

${ }^{1}$ Dark gray indicates the percentage of respondents is higher than $50 \%$, while light gray indicates response rates between 30 and $50 \%{ }^{2}$ Results are based on Fisher's exact test. NS: no statistically significant association $(p>0.1)$. Statistically significant associations $(p<0.05)$ are emphasized in boldface. 
Table 4. Action variables identified in mental models and their citation frequency.

\begin{tabular}{|c|c|c|c|c|c|c|}
\hline Category & Variables & $\begin{array}{c}\text { Citation } \\
\text { Frequency }\end{array}$ & $\begin{array}{c}\text { Dairy Farmers } \\
\text { No. }\left(\%^{1}\right)\end{array}$ & $\begin{array}{c}\text { Arable Farmers } \\
\text { No. }\left(\%^{1}\right)\end{array}$ & $\begin{array}{c}\text { Non-Farmers } \\
\text { No. }\left(\%^{1}\right)\end{array}$ & $p^{2}$ \\
\hline \multirow{5}{*}{ Biogas plant } & Establishment of the joint biogas plant to share costs & 8 & $5(71)$ & 0 & $3(38)$ & 0.021 \\
\hline & Continuation of the current FIT or even raising the purchase price & 7 & $3(43)$ & 0 & $4(50)$ & NS \\
\hline & Subsidy for plant construction & 4 & $1(14)$ & $1(14)$ & $2(25)$ & NS \\
\hline & R\&D for low-costs, high-productivity, and user-friendly biogas production and utilization & 3 & 0 & 0 & $3(38)$ & 0.082 \\
\hline & Improvement of power distribution/transmission environment & 3 & 0 & 0 & $3(38)$ & 0.082 \\
\hline \multirow{7}{*}{ Digestate } & Subsidy for new equipment and using a contractor to handle/spread digestate & 7 & $4(57)$ & $3(43)$ & 0 & 0.058 \\
\hline & Clarification of the actual merits of digestate as fertilizer & 6 & $2(29)$ & $3(43)$ & $1(13)$ & NS \\
\hline & Technical support to develop a crop nutrition plan including digestate use & 5 & $1(14)$ & $2(29)$ & $2(25)$ & NS \\
\hline & Upgrading to be more user-friendly & 4 & 0 & $4(57)$ & 0 & 0.010 \\
\hline & Providing and spreading digestate in low price or free of charge & 4 & 0 & $3(43)$ & $1(13)$ & NS \\
\hline & Organizing a study group, match-making between digestate supplier and demander & 4 & $1(14)$ & $2(29)$ & $1(13)$ & NS \\
\hline & Supplier's improved understanding of user's needs (e.g., timing and amount of spread) & 2 & 0 & $2(29)$ & 0 & NS \\
\hline \multirow{4}{*}{$\begin{array}{l}\text { Local } \\
\text { community }\end{array}$} & Use of energy and heat in, e.g., public buildings and horticulture & 5 & $1(14)$ & 0 & $4(50)$ & 0.081 \\
\hline & Use the biogas plants as a tool in environmental education & 2 & 0 & 0 & $2(25)$ & NS \\
\hline & Establishment of municipal electric power systems & 2 & 0 & 0 & $2(25)$ & NS \\
\hline & Open new markets for digestate products (e.g., use digestate in organic farming) & 1 & 0 & 0 & $1(13)$ & NS \\
\hline
\end{tabular}

${ }^{1}$ Dark gray indicates the percentage of respondents is higher than $50 \%$, while light gray indicates response rates between 30 and $50 \% .{ }^{2}$ Results are based on Fisher's exact test. NS: no statistically significant association $(p>0.1)$. Statistically significant associations $(p<0.05)$ are emphasized in boldface. 
Finally, citation frequencies of motivation, constraint, and action variables were compared among three groups of stakeholders: dairy farmers, arable farmers, and non-farmers (Tables 2-4). These comparisons were made with respect to biogas plant installation, digestate use as a fertilizer, and impacts of biogas and digestate use on the local community. The most frequently mentioned variables in the mental models produce a sense of the most important features affecting the different stakeholders. Fisher's exact test was applied to investigate similarities and differences among the stakeholder groups at a significance level of 0.1. No quantitative analysis of mental model structure was conducted in this study, but it will be addressed in an upcoming article. Rather, we used a qualitative analysis of the interview recordings to understand how and why different factors impacted stakeholders' views of biogas systems.

\section{Results}

\subsection{Motivations}

Table 1 displays the motivation variables that the stakeholders presented. The most frequently mentioned benefit of biogas installation for all stakeholders was the additional source of income generated from electricity sales. Seven of the stakeholders also mentioned that plant installation would be essential for dairy farmers who intend to increase the number of dairy cattle (farm enlargement). This is because biogas plants are believed to be an appropriate means of handling large amounts of slurry manure, which reduces workload for manure handling. In addition, biogas plants were seen by all groups as an effective way of reducing energy costs through self-provision. In particular, dairy farmers appreciated the use of co-generated heat for processing raw milk.

Regarding the benefits of digestate use, the main motivation for all three groups was the reduction in odor from spreading digestate compared to conventional composts. Half of the stakeholders expected reduced fertilizer costs by substituting commercial fertilizers for digestate. Some stakeholders saw digestate as a quick-release nitrogen fertilizer that would be valuable in grasslands. In addition, anaerobic digestion of manure was perceived to be effective for inactivating weed seeds mixed in manure.

At the local community level, 12 stakeholders from all three groups considered that biogas systems had environmental benefits, such as reduced nitrogen leaching, odors, and GHG emissions. Nearly half of the non-farmers believed that wide implementation of biogas systems can lead to energy self-sufficiency and a ripple effect on the local economy (e.g., creation of new jobs). Compared to non-farmers, dairy and arable farmers tended to be less motivated by these benefits to the local community. However, dairy farmers believed that wide implementation of biogas systems, including improvement of barn environments (e.g., less disposal of manure within a farm) and reduction of manure odor, would lead to an improved image of dairy farming in general.

\subsection{Constraints}

Table 2 displays stakeholders' cognitive constraint variables. Financial issues were the most frequently mentioned constraints related to biogas plants. In particular, 15 stakeholders, including all dairy farmers, pointed out the high costs of plant construction. Eight of them also mentioned that this is the critical barrier preventing small- and medium-sized dairy producers from setting up a biogas plant.

Among non-farmers, more than half of them were unsatisfied with the current situation of electric power sale (i.e., limited grid access due to a monopoly of Japan's electric power system and competition with other renewable energy companies, such as solar). Three out of four dairy farmers without the plant noted risks of future policy changes around renewable energy production support (e.g., reduction of FIT), and they thought this lack of long-term stability would be a potential barrier to install biogas plant on their farms. 
More than $70 \%$ of dairy farmers were concerned about handling such large amounts of digestate if more biogas plants would be installed in the town. The main future threat they perceived was potentially higher competition for gaining access to fields as the number of biogas plants increased in the neighborhood. Three arable farmers also mentioned the same concern.

Most arable farmers were not inclined to use digestate as a substitute for chemical fertilizer regardless of their previous digestate use. The top six mentioned constraints included: (1) distance and costs for digestate transportation; (2) limited timing and conditions for application, because liquid digestate cannot be spread on rainy and windy days or on sloping fields; (3) unclear impacts on yield; (4) risk of soil compaction by heavy digestate spreaders; (5) preference of solid composted manure over liquid digestate; and (6) high variability of nutrient contents and dry matter contents. Conventional compost can be stored on a shelf, but liquid digestate requires a storage tank and re-application of composted manure as a soil amendment, causing extra application costs. In contrast to the major cognitive motivation of reducing odor (Table 2), two arable farmers still perceived that digestate has an unpleasant odor.

In addition to these difficulties for the actual usage of digestate, non-technical constraints also were identified. Some arable farmers were afraid to use it because none of their neighboring farmers used it, while they also felt that there were poor linkages and communication with the dairy farmers who supplied the digestate. In addition, the characteristics of suppliers matter. Some arable farmers, in particular non-digestate users, believed that suppliers were careless about the demand-side wishes (i.e., spreading digestate with proper timing and amount) and instead put greater priority on their disposal of digestate.

Furthermore, insufficient knowledge of digestate among farmers was regarded as a barrier for successful digestate use. This was mainly due to the limited access of gaining information and meeting experts. It should be noted that most of these technical and non-technical constraints to digestate use were mentioned by arable farmers, while only a few variables were raised by the other two groups.

A few comments on community challenges were found in the mental models of arable and non-farmers. One from each group considered that local people had insufficient knowledge of biogas systems, while one arable farmer felt that only dairy farmers received the benefits of biogas systems, and there were low returns to the whole community.

\subsection{Actions}

The actions that the stakeholders think would be necessary to take for wide implementation and maintenance of biogas system are shown in Table 3. The most frequently mentioned action was to start a new project of joint biogas plants. The joint biogas plant includes co-digestion of cattle manure collected from multiple small- and mid-sized dairy farmers. This action, as a way of sharing various costs, was suggested by eight stakeholders, including all dairy farmers who had no experience with biogas plants. Continuation of or increases in the level of current public support (FIT and construction subsidies) was recommended by dairy and non-farmers.

The majority of non-farmers thought that more technical development is needed to produce biogas at lower costs and with more efficiency for further promotion of biogas plant installation. Government financial support for engineers and researchers was recommended. Simplification of the technology, leading to more user-friendly operation systems, also was suggested.

Regarding the actions for stimulating digestate use, the most common suggestion (from seven of the dairy and arable farmers) was increased financial support to purchase new equipment, such as spreaders, and the use of contractors who can handle digestate collection and spreading on behalf of plant operators. On the contrary, more than $40 \%$ of arable farmers believed that plant operators (i.e., dairy farmers) should spread digestate free of charge and with proper timing and amounts.

When looking at suggestions raised by arable farmers, the most popular action was to clarify the actual merits of digestate as a fertilizer. This includes chemical analysis of nutrient contents and field experiments of digestate application. The second most frequent suggestion was to upgrade 
digestate to be more user-friendly. For example, this includes (1) treating digestate to homogenize nutrient contents, (2) upgrading digestate to a solid or concentrated product, (3) downsizing digestate spreaders to avoid soil compaction, and (4) providing sub-tanks for digestate storage near the fields to avoid frequent round trips between a plant and the fields.

The stakeholders, mainly arable farmers, mentioned that more action would be needed to overcome non-technical constraints on digestate use. These actions include organizing a study group to learn how to use digestate, setting up a place where digestate suppliers and receivers can be matched up, and developing a decision support system through which arable farmers can be supported to make a crop nutrient plan for digestate use. Some farmers expect that JA Shihoro may play a significant role in coordinating a study group and matching.

In order to take advantage of the benefits or to overcome the barriers to biogas systems at the community level, some stakeholders, in particular non-farmers, noted several actions. The most frequent suggestion was to expand the energy use system outside of dairy farms. This includes application of co-generated heat to greenhouse farming and public buildings.

\section{Discussion}

\subsection{Similarities in Perception of Biogas Systems}

The creation of mental models among the various biogas stakeholders revealed similarities and differences among each variable type. Stakeholders commonly perceive that the benefits of biogas systems can bring (1) additional sources of income, (2) reduced energy costs through self-provision, (3) reduced odor from spreading digestate compared to composted manure, (4) reduced fertilizer costs through digestate substitution, and (5) various environmental benefits (Table 1). These five benefits are identified widely in the literature $[1,4,15,53]$, confirming that the majority of stakeholders hold the same basic understanding of what biogas systems can offer. Although earlier studies found that social acceptability of biogas plants remains a key constraint preventing its widespread deployment [54,55], public opposition toward installing biogas plant was observed rarely in the mental models of the Shihoro stakeholders. This can be attributed to initiatives made by the municipalities and JA Shihoro that play a vital role in supporting biogas projects [56]. Several authors propose that local initiatives on climate change and environmental protection are effective approaches for improving the community's understanding of renewable energy systems and to enhance local involvement to generate needed support [55]. In Shihoro, environmental benefits at the local community level are understood by the majority of stakeholders, suggesting that there is a huge potential for further expansion of biogas systems.

\subsection{Differences in Perception as Potential Constraints for Further Expansion of Biogas Systems}

Our study found that most dairy farmers and non-farmers have focused on the input side of their business, concentrating their resources on energy production (i.e., most variables raised were related to biogas plants). As a result, the digestate side of biogas production has been largely neglected by these two groups (Table 3). Moreover, most arable farmers expressed hesitation to accept digestate as an appropriate fertilizer due to several technical and non-technical constraints (Table 2).

There appear to be three issues causing the perception differences regarding digestate use. First, dairy farmers and non-farmers have overlooked these technical and non-technical constraints because they already believe that digestate is a valuable fertilizer. This is confirmed by our results in Table 3 where the two groups came up with only a few action suggestions for promoting digestate use (Table 3), meaning they rarely see any problems with it. Second, arable farmers appear to be comparing digestate to conventional mineral fertilizers and composted manure. Mineral fertilizers are superior to digestate in terms of nutrient contents and effects on crop growth and yield, while solid composted manure has better storage options and can improve the structure of soil properties [5,57]. Although farming characteristics (e.g., farming activity, farmer age, farm size, and conventional/organic farming) impact 
their decisions [58], such shortcomings affect the perceived value of digestate and its acceptance by the majority of arable farmers. Third, in addition to quality assessment of digestate, arable farmers care about the social relationship with digestate suppliers. Within these rural communities, embedded social networks related to social capital have been built upon trust and communication, and play important roles in collective actions [59-61]. These close ties offer participants more chances to exclude risk and uncertainty. In our study, three of the seven arable farmers who received digestate mentioned that they received it because of trustworthy relationships with their supplier. According to their explanation, this trust was built upon their previous knowledge of the supplier's professional skills and business expertise, as well the supplier's careful attention toward farmland management. This finding is in line with that of Asai et al. [62,63], who found that a trustworthy relationship is one of the critical factors affecting whether livestock and arable farmers establish a collaborative partnership. This indicates that improved understanding of the demand side by dairy farmers may drastically change the acceptance rate among arable farmers. Appreciation of trusting relationships should be more important in the case of on-farm biogas plants than in the case of centralized biogas plants because an on-farm plant operator is usually expected to make arrangements with arable farmers individually.

\subsection{Policy Implications for the Potential Constraints}

The continuation of FIT and subsidies for plant construction appears to be a prerequisite for further expansion of biogas systems in Shihoro, as farmers' willingness to adopt plants depend on the availability of subsidies (Table 3). However, our results reveal that this energy policy must be implemented in cooperation with agri-environmental policies related to digestate use. The current energy policy provides incentives to dairy farmers to increase the number of animals to produce more manure and to increase the farm's turnover [64]. This produces further environmental risks for atmospheric and nutrient pollution when proper handling and management of digestate is missing [5]. These negative externalities have already been discussed with respect to other countries, such as Italy [64] and Germany [65].

To prevent further ecological load on the land as a consequence of expanding the number and capacity of biogas plants, one solution is to implement mandatory planning of digestate utilization when new biogas plants are constructed. This legal framework for assessing regional fertilization potential in agriculture can be useful, because it avoids over-fertilization and thus promotes optimal nutrient recycling [66]. In Denmark, planning of digestate utilization is not mandatory, but farmers are obliged to achieve the required balance between the crop area and manure produced at the farm level, and thus to submit annual fertilizer accounts to the authorities who report on produced, applied, received, and provided fertilizer and manure under the Water Framework Directive (2000/60/EC) [67]. This Danish regulation also applies to digestate handling and thus requires digestate users are located prior to planning a new biogas plant.

The legal framework has to be in cooperation with other policies to alleviate demand-side barriers. More efforts are needed to improve the attractiveness of digestate for arable farmers. Below, we provide several possible actions to address these barriers, based on the propositions made by Case et al. [58] for promotion of organic fertilizers and by stakeholders in Shihoro (actions in Table 3). These actions can be enacted by a mix of industry, academia, and governmental policy interventions [58].

Demand-side barriers to digestate use were related to the cost of digestate use, including transport and equipment, such as spreaders and storage tanks. Reducing costs for digestate use could come via subsidies for new and more appropriate equipment to handle or spread digestate, or to outsource extra workload for digestate handling. Uncertainty in nutrient content also was perceived as a constraint to more widespread digestate use. Improved testing and validation of fertilizer value are necessary, such as recently available online sensors for measuring nutrient content of manure and digestate [58]. In some European countries, a quality management system for digestate is commonly adopted to avoid conflicts between digestate providers and users [68]. In Japan, however, the installation of this 
kind of system is rarely seen in the most biogas plants. Financial support for plant operators to adopt these technologies results in enabling accurate dosing of the digestate.

Technological innovation is needed to address demand-side barriers related to the unattractive properties of digestate, including that it is a liquid, its odor, and its nutrient (NPK) contents (Table 2). According to Dahlin et al. [69], there are several technologies available that range from simple (e.g., a solid-liquid separator to separate nitrogen and phosphorous) to very sophisticated (e.g., ammonia stripping, membrane processes, and vacuum evaporation). However, several of these technologies are costly, so further research on, and the development of, lower cost options should be targeted by increasing research funding in academia and industry.

Finally, information sharing and outreach activities are essential. In the mental models of arable farmers, some respondents indicated that they had no chance to learn about digestate and that therefore they were not interested in it. Governments can motivate potential users by distributing information on successful cases and holding outreach events to identify the environmental and economic benefits of digestate use. Another key strategy may be for policy makers to make use of local leaders or "reference farmers," who have an influence on other farmers' behaviors to promote digestate use. This may be a more cost-effective approach to encourage other farmers and local communities to develop positive attitudes toward the use of digestate.

\section{Conclusions}

Biogas systems are local and complex systems, involving many stakeholders affecting input (manure and residues) and output (biogas, digestate, energy, and heat) use within a community. Once the systems are managed properly, there is a high potential to provide multiple environmental and socioeconomic benefits to the community. However, implementation and widespread adoption of biogas systems are challenging because of differences in values and perspectives of biogas systems among the diverse set of stakeholders. Thus, this study aimed to understand similarities and differences in the views of biogas systems among its stakeholders by creating mental models among stakeholders in Shihoro, Japan.

Our results show that stakeholders in Shihoro shared the same motivations toward accepting biogas systems, including expected environmental benefits. This finding indicates that there is a high potential for further expansion. However, differences were also found: arable farmers were not attracted to digestate use due to several technical and non-technical constraints, while dairy farmers and non-farmers were ambivalent about these demand-side constraints. From both economic and environmental points of view, this difference in perception may lead to future conflict regarding digestate disposal that represents a potential obstacle for further expansion. Therefore, biogas energy policy must be implemented in cooperation with agri-environmental policies related to digestate use. Implementation of mandatory planning of digestate use when planning a new biogas plant is one option, and policies could be developed to improve the attractiveness of digestate for farmers. The findings and suggestions from this study should be useful for other livestock-intensive areas of Japan and other countries, in particular where the number of biogas plants is rapidly increasing but the management system of the digestate produced has yet to be organized.

Several studies have indicated that, if a biogas system brings about localized benefits, it is likely to be sustained over the long term $[16,64,70-72]$. The localized benefits do not have to refer only to energy supply [16]. Our approach, using mental models to understand various stakeholders' perceptions, motivations, constraints, and actions related to biogas systems, explored a possible roadmap to achieve localized benefits. The next step is to share mental models obtained among various stakeholders in a workshop. This can improve understanding and social learning, and thus better support the establishment of sustainable biogas systems.

Author Contributions: M.A., T.H., and M.Y. designed the study, M.A. and T.H. conducted the interviews and analysis, and M.A. wrote the manuscript. All authors commented on and approved the manuscript. 
Acknowledgments: This work was supported by JSPS KAKENHI Grant Numbers JP26281060, JP17H01928, and JP15K18755. We thank the 22 stakeholders for their participation in the study. Special thanks are extended to Kouichi Nishida (JA Shihoro) for his contribution in organizing interviews with farmers. We are grateful to Kazutaka Umetsu (Obihiro University of Agriculture and Veterinary Medicine) and Yoshiteru Takeuchi (BIRD) for their valuable information. We also thank Daisuke Kunii (PRIMAFF) for providing us with the map of Shihoro.

Conflicts of Interest: The authors declare no conflict of interest.

\section{References}

1. Holm-Nielsen, J.B.; Al Seadi, T.; Oleskowicz-Popiel, P. The future of anaerobic digestion and biogas utilization. Bioresour. Technol. 2009, 100, 5478-5484. [CrossRef] [PubMed]

2. Weiland, P. Biogas production: Current state and perspectives. Appl. Microbiol. Biotechnol. 2010, 85, 849-860. [CrossRef] [PubMed]

3. Aryal, N.; Kvist, T.; Ammam, F.; Pant, D.; Ottosen, L.D.M. An overview of microbial biogas enrichment. Bioresour. Technol. 2018, 264, 359-369. [CrossRef] [PubMed]

4. Huttunen, S.; Manninen, K.; Leskinen, P. Combining biogas LCA reviews with stakeholder interviews to analyse life cycle impacts at a practical level. J. Clean. Prod. 2014, 80, 5-16. [CrossRef]

5. Nkoa, R. Agricultural benefits and environmental risks of soil fertilization with anaerobic digestates: A review. Agron. Sustain. Dev. 2014, 34, 473-492. [CrossRef]

6. Mol, A.P.J. Bounded Biofuels? Sustainability of Global Biogas Developments. Sociol. Rural. 2014, 54, 1-20. [CrossRef]

7. Pan, S.-Y.; Du, M.A.; Huang, I.-T.; Liu, I.-H.; Chang, E.-E.; Chiang, P.-C. Strategies on implementation of waste-to-energy (WTE) supply chain for circular economy system: A review. J. Clean. Prod. 2015, 108, 409-421. [CrossRef]

8. Edwards, J.; Othman, M.; Burn, S. A review of policy drivers and barriers for the use of anaerobic digestion in Europe, the United States and Australia. Renew. Sustain. Energy Rev. 2015, 52, 815-828. [CrossRef]

9. Capodaglio, A.G.; Callegari, A.; Lopez, M.V. European Framework for the Diffusion of Biogas Uses: Emerging Technologies, Acceptance, Incentive Strategies, and Institutional-Regulatory Support. Sustainability 2016, 8, 298. [CrossRef]

10. Tranter, R.B.; Swinbank, A.; Jones, P.J.; Banks, C.J.; Salter, A.M. Assessing the potential for the uptake of on-farm anaerobic digestion for energy production in England. Energy Policy 2011, 39, 2424-2430. [CrossRef]

11. Qu, W.; Tu, Q.; Bluemling, B. Which factors are effective for farmers' biogas use?-Evidence from a large-scale survey in China. Energy Policy 2013, 63, 26-33. [CrossRef]

12. Brudermann, T.; Mitterhuber, C.; Posch, A. Agricultural biogas plants-A systematic analysis of strengths, weaknesses, opportunities and threats. Energy Policy 2015, 76, 107-111. [CrossRef]

13. Rupf, G.V.; Bahri, P.A.; de Boer, K.; McHenry, M.P. Barriers and opportunities of biogas dissemination in Sub-Saharan Africa and lessons learned from Rwanda, Tanzania, China, India, and Nepal. Renew. Sustain. Energy Rev. 2015, 52, 468-476. [CrossRef]

14. Mwirigi, J.; Balana, B.B.; Mugisha, J.; Walekhwa, P.; Melamu, R.; Nakami, S.; Makenzi, P. Socio-economic hurdles to widespread adoption of small-scale biogas digesters in Sub-Saharan Africa: A review. Biomass Bioenergy 2014, 70, 17-25. [CrossRef]

15. Lantz, M.; Svensson, M.; Björnsson, L.; Börjesson, P. The prospects for an expansion of biogas systems in Sweden-Incentives, barriers and potentials. Energy Policy 2007, 35, 1830-1843. [CrossRef]

16. Bluemling, B.; Mol, A.P.J.; Tu, Q. The social organization of agricultural biogas production and use. Energy Policy 2013, 63, 10-17. [CrossRef]

17. Biggs, D.; Abel, N.; Knight, A.T.; Leitch, A.; Langston, A.; Ban, N.C. The implementation crisis in conservation planning: Could "mental models" help? Conserv. Lett. 2011, 4, 169-183. [CrossRef]

18. Moon, K.; Adams, V.M. Using quantitative influence diagrams to map natural resource managers' mental models of invasive species management. Land Use Policy 2016, 50, 341-351. [CrossRef]

19. Alburquerque, J.A.; de la Fuente, C.; Campoy, M.; Carrasco, L.; Nájera, I.; Baixauli, C.; Caravaca, F.; Roldán, A.; Cegarra, J.; Bernal, M.P. Agricultural use of digestate for horticultural crop production and improvement of soil properties. Eur. J. Agron. 2012, 43, 119-128. [CrossRef]

20. Bougnom, B.P.; Niederkofler, C.; Knapp, B.A.; Stimpfl, E.; Insam, H. Residues from renewable energy production: Their value for fertilizing pastures. Biomass Bioenergy 2012, 39, 290-295. [CrossRef] 
21. Dahlin, J.; Herbes, C.; Nelles, M. Biogas digestate marketing: Qualitative insights into the supply side. Resour. Conserv. Recycl. 2015, 104, 152-161. [CrossRef]

22. Hansen, P. Becoming bovine: Mechanics and metamorphosis in Hokkaido's animal-human-machine. J. Rural Stud. 2014, 33, 119-130. [CrossRef]

23. Lybæk, R.; Asai, M. Future Pathways for Deploying Agricultural Based Biogas Plants in Denmark and Japan: A Comparative Analysis. GMSARN Int. J. 2017, 11, 129-138.

24. Kuzuhara, Y. Biomass Nippon Strategy-Why “Biomass Nippon” now? Biomass Bioenergy 2005, 29, 331-335. [CrossRef]

25. Matsumura, Y.; Yokoyama, S. Current situation and prospect of biomass utilization in Japan. Biomass Bioenergy 2005, 29, 304-309. [CrossRef]

26. Iwasaki, M.; Takeuchi, Y.; Umetsu, K. Recent Development in Research and Technology Related to Agricultural Facilities: Livestock Manure-based Methane Fermentation Systems. J. Soc. Agr. Struct. Jpn. 2017, 48, 123-130. (In Japanese)

27. METI. Feed-in Tariff Scheme in Japan. Available online: http://www.meti.go.jp/english/policy/energy_ environment/renewable/pdf/summary201207.pdf (accessed on 4 January 2019).

28. MAFF. Biomass Industrialization Strategy (In Japanese). Available online: http://www.maff.go.jp/j/press / shokusan/bioi/pdf/120906-02.pdf (accessed on 4 January 2019).

29. Matsuda, J. Large-scaled Biogas Plant in Betsukai town. Livestock Ind. Environ. Inf. 2016, 62, 1-14. (In Japanese). Available online: https://www.leio.or.jp/pub_train/publication/tkj/tkj62/tkj62-1.pdf (accessed on 4 January 2019).

30. Chen, W.-M.; Kim, H.; Yamaguchi, H. Renewable energy in eastern Asia: Renewable energy policy review and comparative SWOT analysis for promoting renewable energy in Japan, South Korea, and Taiwan. Energy Policy 2014, 74, 319-329. [CrossRef]

31. Town of Shihoro. Geography, climate and population of Shioro. Available online: http:/ /www.shihoro.jp/ tem/ (accessed on 4 January 2019).

32. Koga, N.; Sawamoto, T.; Tsuruta, H. Life cycle inventory-based analysis of greenhouse gas emissions from arable land farming systems in Hokkaido, northern Japan. Soil Sci. Plant Nutr. 2006, 52, 564-574. [CrossRef]

33. JA Shihoro. Development of biomass projects in Shihoro (In Japanese). Available online: http:/ / www.pref. hokkaido.lg.jp/ks/tot/biomassnetwork/H28houkokukaisiryou310.pdf (accessed on 4 January 2019).

34. Hoffman, M.; Lubell, M.; Hillis, V. Linking knowledge and action through mental models of sustainable agriculture. Proc. Natl. Acad. Sci. USA 2014, 111, 13016-13021. [CrossRef]

35. Jones, N.; Ross, H.; Lynam, T.; Perez, P.; Leitch, A. Mental Models: An Interdisciplinary Synthesis of Theory and Methods. Ecol. Soc. 2011, 16, 46. [CrossRef]

36. Craik, K.J.W. The Nature of Explanation; Cambridge University Press: Cambridge, UK, 1967; ISBN 9780521094450 .

37. Wood, M.D.; Bostrom, A.; Bridges, T.; Linkov, I. Cognitive Mapping Tools: Review and Risk Management Needs. Risk Anal. 2012, 32, 1333-1348. [CrossRef] [PubMed]

38. Du Toit, D.; Biggs, H.; Pollard, S. The Potential Role of Mental Model Methodologies in Multistakeholder Negotiations: Integrated Water Resources Management in South Africa. Ecol. Soc. 2011, 16, 21. [CrossRef]

39. Meliadou, A.; Santoro, F.; Nader, M.R.; Dagher, M.A.; Al Indary, S.; Salloum, B.A. Prioritising coastal zone management issues through fuzzy cognitive mapping approach. J. Environ. Manag. 2012, 97, 56-68. [CrossRef] [PubMed]

40. Özesmi, U.; Özesmi, S.L. Ecological models based on people's knowledge: A multi-step fuzzy cognitive mapping approach. Ecol. Model. 2004, 176, 43-64. [CrossRef]

41. Douglas, E.M.; Wheeler, S.A.; Smith, D.J.; Overton, I.C.; Gray, S.A.; Doody, T.M.; Crossman, N.D. Using mental-modelling to explore how irrigators in the Murray-Darling Basin make water-use decisions. J. Hydrol. 2016, 6, 1-12. [CrossRef]

42. Jetter, A.; Schweinfort, W. Building scenarios with Fuzzy Cognitive Maps: An exploratory study of solar energy. Futures 2011, 43, 52-66. [CrossRef]

43. Kermagoret, C.; Levrel, H.; Carlier, A.; Ponsero, A. Stakeholder Perceptions of Offshore Wind Power: A Fuzzy Cognitive Mapping Approach. Soc. Nat. Resour. 2016, 29, 916-931. [CrossRef]

44. Konti, A.; Damigos, D. Exploring strengths and weaknesses of bioethanol production from bio-waste in Greece using Fuzzy Cognitive Maps. Energy Policy 2018, 112, 4-11. [CrossRef] 
45. Kontogianni, A.; Tourkolias, C.; Papageorgiou, E.I. Revealing market adaptation to a low carbon transport economy: Tales of hydrogen futures as perceived by fuzzy cognitive mapping. Int. J. Hydrogen Energy 2013, 38, 709-722. [CrossRef]

46. Grenier, R.S.; Dudzinska-Przesmitzki, D. A Conceptual Model for Eliciting Mental Models Using a Composite Methodology. Hum. Resour. Dev. Rev. 2015, 14, 163-184. [CrossRef]

47. Jones, N.; Ross, H.; Lynam, T.; Perez, P. Eliciting Mental Models: A Comparison of Interview Procedures in the Context of Natural Resource Management. Ecol. Soc. 2014, 19, 13. [CrossRef]

48. Christen, B.; Kjeldsen, C.; Dalgaard, T.; Martin-Ortega, J. Can fuzzy cognitive mapping help in agricultural policy design and communication? Land Use Policy 2015, 45, 64-75. [CrossRef]

49. Olazabal, M.; Pascual, U. Use of fuzzy cognitive maps to study urban resilience and transformation. Environ. Innov. Soc. Transit. 2016, 18, 18-40. [CrossRef]

50. Vuillot, C.; Coron, N.; Calatayud, F.; Sirami, C.; Mathevet, R.; Gibon, A. Ways of farming and ways of thinking: Do farmers' mental models of the landscape relate to their land management practices? Ecol. Soc. 2016, 21, 35. [CrossRef]

51. Etienne, M.; Du Toit, D.; Pollard, S. ARDI: A Co-construction Method for Participatory Modeling in Natural Resources Management. Ecol. Soc. 2011, 16, 44. [CrossRef]

52. Gray, S.; Chan, A.; Clark, D.; Jordan, R. Modeling the integration of stakeholder knowledge in social-ecological decision-making: Benefits and limitations to knowledge diversity. Ecol. Model. 2012, 229, 88-96. [CrossRef]

53. Röder, M. More than food or fuel. Stakeholder perceptions of anaerobic digestion and land use; a case study from the United Kingdom. Energy Policy 2016, 97, 73-81. [CrossRef]

54. Mbzibain, A.; Hocking, T.J.; Tate, G.; Ali, S. Renewable enterprises on UK farms: Assessing levels of uptake, motivations and constraints to widespread adoption. Biomass Bioenergy 2013, 49, 28-37. [CrossRef]

55. Upreti, B.R.; van der Horst, D. National renewable energy policy and local opposition in the UK: The failed development of a biomass electricity plant. Biomass Bioenergy 2004, 26, 61-69. [CrossRef]

56. Lybæk, R.; Kjær, T. Municipalities as facilitators, regulators and energy consumers for enhancing the dissemination of biogas technology in Denmark. Int. J. Sustain. Energy Plan. Manag. 2015, 8, 17-30.

57. Hou, Y.; Velthof, G.L.; Case, S.D.C.; Oelofse, M.; Grignani, C.; Balsari, P.; Zavattaro, L.; Gioelli, F.; Bernal, M.P.; Fangueiro, D.; et al. Stakeholder perceptions of manure treatment technologies in Denmark, Italy, the Netherlands and Spain. J. Clean. Prod. 2018, 172, 1620-1630. [CrossRef]

58. Case, S.D.C.; Oelofse, M.; Hou, Y.; Oenema, O.; Jensen, L.S. Farmer perceptions and use of organic waste products as fertilisers-A survey study of potential benefits and barriers. Agric. Syst. 2017, 151, 84-95. [CrossRef]

59. Breetz, H.L.; Fisher-Vanden, K.; Jacobs, H.; Schary, C. Trust and Communication: Mechanisms for Increasing Farmers' Participation in Water Quality Trading. Land Econ. 2005, 81, 170-190. [CrossRef]

60. Morrison, M.; Oczkowski, E.; Greig, J. The primacy of human capital and social capital in influencing landholders' participation in programmes designed to improve environmental outcomes. Aust. J. Agric. Resour. Econ. 2011, 55, 560-578. [CrossRef]

61. Pretty, J.; Smith, D. Social Capital in Biodiversity Conservation and Management. Conserv. Biol. 2004, 18, 631-638. [CrossRef]

62. Asai, M.; Moraine, M.; Ryschawy, J.; de Wit, J.; Hoshide, A.K.; Martin, G. Critical factors for crop-livestock integration beyond the farm level: A cross-analysis of worldwide case studies. Land Use Policy 2018, 73, 184-194. [CrossRef]

63. Asai, M.; Langer, V.; Frederiksen, P.; Jacobsen, B.H. Livestock farmer perceptions of successful collaborative arrangements for manure exchange: A study in Denmark. Agric. Syst. 2014, 128, 55-65. [CrossRef]

64. Carrosio, G. Energy production from biogas in the Italian countryside: Policies and organizational models. Energy Policy 2013, 63, 3-9. [CrossRef]

65. Reise, C.; Musshoff, O.; Granoszewski, K.; Spiller, A. Which factors influence the expansion of bioenergy? An empirical study of the investment behaviours of German farmers. Ecol. Econ. 2012, 73, 133-141. [CrossRef]

66. Tampio, E.; Lehtonen, E.; Kinnunen, V.; Mönkäre, T.; Ervasti, S.; Kettunen, R.; Rasi, S.; Rintala, J. A demandbased nutrient utilization approach to urban biogas plant investment based on regional crop fertilization. J. Clean. Prod. 2017, 164, 19-29. [CrossRef] 
67. Asai, M.; Langer, V.; Frederiksen, P. Responding to environmental regulations through collaborative arrangements: Social aspects of manure partnerships in Denmark. Livest. Sci. 2014, 167, 370-380. [CrossRef]

68. ECN-QAS. European Compost Network. Available online: https://www.compostnetwork.info/ecn-qas / (accessed on 3 December 2018).

69. Dahlin, J.; Nelles, M.; Herbes, C. Biogas digestate management: Evaluating the attitudes and perceptions of German gardeners towards digestate-based soil amendments. Resour. Conserv. Recycl. 2017, 118, 27-38. [CrossRef]

70. Asai, M.; Takai, H. Danish Biogas Policies and Partnerships among Prominent Actors in the Biogas Sector: Lessons Learnt from Two Newly Developed Biogas Projects. J. Agric. Policy Res. 2017, 25-47. (In Japanese)

71. He, G.; Bluemling, B.; Mol, A.P.J.; Zhang, L.; Lu, Y. Comparing centralized and decentralized bio-energy systems in rural China. Energy Policy 2013, 63, 34-43. [CrossRef]

72. Aryal, N.; Kvist, T. Alternative of Biogas Injection into the Danish Gas Grid System-A Study from Demand Perspective. ChemEngineering 2018, 2, 43. [CrossRef]

(C) 2019 by the authors. Licensee MDPI, Basel, Switzerland. This article is an open access article distributed under the terms and conditions of the Creative Commons Attribution (CC BY) license (http:/ / creativecommons.org/licenses/by/4.0/). 